\title{
Analisis Kinerja SI/TI Pada PDAM Kota Salatiga Menggunakan Kerangka IT Balanced Scorecard
}

\author{
Septi Wiyono ${ }^{1}$, Andeka Rocky Tanaamah ${ }^{2}$ \\ ${ }^{1,2}$ Program Studi Sistem Informasi, Fakultas Teknologi Informasi, Universitas Kristen Satya Wacana \\ J1. Diponegoro 52-60, Salatiga 50711 \\ E-mail: 682013006@student.uksw.edu, atanaamah@staff.uksw.edu
}

Masuk: 2 Juni 2017; Direvisi: 31 Juli 2017; Diterima: 13 Agustus 2017

\begin{abstract}
Customer Service Application has an important role in improving the quality of service in PDAM Salatiga city. Referring to this understanding, the existence of a customer service application in PDAM is considered very essentialtoimprove the employees' performance in providing a better customer service. This researchtries to see how IS/IT measures can improve the effectiveness of the various perspectives used. As the findings in this research show how customer service applications can provide values for the company and improve the employees' performance. Customer service applications have an important role in various ways, in this research application performance measured in order to increase employees satisfaction to the company.
\end{abstract}

Keywords: Performance SI/IT, IT Balanced Scorecard, Customer Service Application.

\begin{abstract}
Abstrak. Analisis Kinerja SI/TI pada PDAM Kota Salatiga Menggunakan Kerangka IT Balanced Scorecard. Aplikasi Pelayanan Pelanggan memiliki peran penting dalam meningkatkan kualitas pelayanan bagi PDAM Kota Salatiga. Mengacu pada pemahaman tersebut, maka kehadiran aplikasi pelayanan pelanggan di PDAM diposisikan sebagai basis utama dalam meningkatkan kinerja karyawan dalam hal pelayanan pelanggan yang semakin meningkat. Penelitian ini melihat bagaimana mengukur SI/TI yang dapat meningkatkan efektifitas diberbagai perspektif yang digunakan. Adapun temuan-temuan yang diperoleh dalam penelitian ini adalah bagaimana kehadiran aplikasi pelayanan pelanggan dapat memberikan nilai untuk perusahaan dan sarana untuk meningkatkan kinerja karyawan. Aplikasi pelayanan pelanggan memiliki peranan penting dalam meningkatkan efisiensi dan efektifitas dalam perusahaan di berbagai hal, dalam penelitian ini dilakukan pengukuran bagaimana aplikasi dapat meningkatkan kepuasan karyawan terhadap perusahaan.
\end{abstract}

Kata kunci: Kinerja SI/TI, IT Balanced Scorecard, Aplikasi Pelayanan Pelanggan.

\section{Pendahuluan}

Perkembangan teknologi saat ini sangat berpengaruh bagi setiap perusahaan untuk terus memperbaiki kualitas layanan agar dapat meningkatkan kepuasan pelanggan. Yang terjadi adalah faktor finansial sampai saat ini menjadi tolok ukur utama bagi perusahaan untuk melihat apakah kinerja yang ada sudah baik atau belum. Padalah bukan hanya faktor finansial yang dapat mempengaruhi kinerja perusahaan. Oleh karena itu dibutuhkan beberapa tolok ukur selain faktor tersebut untuk membuat kinerja perusahaan dapat meningkat (Solechan, 2015). PDAM Kota Salatiga adalah BUMD yang bergerak dalam penyediaan air minum untuk wilayah Kota Salatiga. PDAM Kota Salatiga memiliki berbagai sistem dan aplikasi yang saling terintegrasi antar bagian, salah satu aplikasi tersebut dapat memasukkan data pembayaran tagihan air yang telah terkoneksi ke semua cabang. Aplikasi tersebut digunakan untuk mempermudah pelaporan tagihan air warga Kota Salatiga. Akan tetapi ada beberapa fungsi yang menurut karyawan PDAM belum dapat dimaksimalkan, yang seharusnya dapat membantu dalam memudahkan suatu pekerjaan. Oleh karena itu terkadang aplikasi menjadi tidak dapat dimaksimalkan oleh 
karyawan PDAM. Untuk itu perlu dilakukan pengukuran terkait kinerja SI/TI yang telah digunakan oleh PDAM Kota Salatiga. Kinerja SI/TI dapat diukur dengan berbagai pendekatan pengukuran kinerja antara lain dengan IT Balanced Scorecard. Sistem pengukuran yang diterapkan perusahaan mempunyai pengaruh yang sangat besar terhadap perilaku manusia di dalam maupun di luar perusahaan (Arofah, dkk., 2012). Saat ini Balanced Scorecard telah diaplikasikan ke dalam dunia teknologi informasi dan lebih dikenal dengan IT Balanced Scorecard. IT Balanced Scorecard menekankan ukuran kinerja berkesinambungan dan merupakan bagian dari sistem informasi pada setiap tingkatan organisasi perusahaan. Seperti para pemangku kebijakan yang harus memahami berbagai faktor yang mendorong keberhasilan finansial dan kinerja jangka panjang (Legoh \& Tambotoh, 2015). IT Balanced Scorecard memberikan kerangka untuk menjabarkan strategi penerapan teknologi informasi dalam perusahaan agar sejalan dengan tujuan, visi dan misi perusahaan. Balanced Scorecard juga dapat diterapkan untuk fungsi IT dan prosesnya (Wijaya, 2015). Tujuan dari penelitian ini adalah agar perusahaan bukan hanya mengukur keberhasilan perusahaan dari perspektif finansial untuk menggambarkan peningkatan kinerja perusahaan. Maka digunakan IT Balanced Scorecard yang memiliki empat perspektif untuk mengukur apakah SI/TI yang diimplementasikan perusahaan telah sesuai dengan apa yang dibutuhkan dan diinginkan karyawan demi meningkatkan kepuasan karyawan terhadap perusahaan.

\section{Kajian Pustaka}

Balanced Scorecard adalah serangkaian pengukuran kinerja untuk perusahaan yang diukur dari empat perspektif berbeda, yaitu Perspektif Keuangan, Perspektif Pelanggan, Proses Bisnis Internal, dan Perspektif Pembelajaran \& Pertumbuhan (Kaplan \& Norton, 2006). IT Balanced Scorecard memiliki tujuan agar para pengguna dapat menyesuaikan perencanaan dan aktivitas pada sistem informasi sebagai kebutuhan organisasi, menyediakan pengukuran untuk mengevaluasi efektivitas sistem informasi, meningkatkan kinerja sistem informasi, dan pencapaian hasil yang seimbang di antara kelompok stakeholder (Kosasi, 2015).

Dari penelitian Maula \& Ghozali (2012) hasil evaluasi kinerja TI menggunakan IT Balanced Scorecard pada PT. XYZ berkesimpulan bahwa fungsi TI dan proses yang selama ini dilakukan, modernisasi perangkat BSC sudah sangat baik dan sesuai dengan visi dan tujuan perusahaan, walaupun dalam prosesnya masih ada beberapa kendala dan kesulitan yang ada, namun sudah dapat ditangani dengan baik.

Penelitian Hidayanto, dkk. (2012) yang dibandingkan dengan situasi sebenarnya pada Direktorat TTKI, dapat disimpulkan bahwa IT Balanced Scorecard dapat memberikan gambaran dalam pengukuran tingkat dukungan TI pada Direktorat TTKI, Direktorat Jenderal Pajak. Hasil pengukuran terhadap efisiensi fungsi layanan masih menunjukkan nilai yang rendah terutama terkait perawatan aplikasi dan kinerja penyelesaian masalah TI. Frekuensi pengecekan ini harus ditingkatkan menjadi satu kali tiap minggu atau empat kali setiap bulan dari satu kali dalam setiap bulan. Pada ukuran strategis rata-rata waktu perbaikan berdasarkan data hasil penelitian rata-rata personil TI membutuhkan waktu satu hingga dua jam untuk memperbaiki setiap kesalahan.

Penelitian Afrianto (2010) IT BSC dapat digunakan untuk mengidentifikasi sistem dan teknologi informasi di Kantor direksi PT.X serta proses-proses TI, Tujuan dan Inisiatif TI dapat diformulasikan. Diperolehnya peta strategi TI yang diharapkan mampu menjadi gambaran dan penerjemahan strategi sistem dan teknologi informasi untuk semua lini di perusahaan.

Penelitian ini mengacu pada penelitian sebelumnya yang bertujuan untuk mengukur kinerja SI/TI menggunakan IT Balanced Scrorecard, didapatkan gambaran tentang bagaimana IT Balanced Scorecard dapat menerjemahkan tujuan strategis perusahaan terhadap TI yang berdampak kepada efisiensi dan fungsi layanan perusahaan. Akan tetapi dalam penelitian sebelumnya analisis mendalam lebih mengarah ke kepuasan konsumen atau pelanggan, pada penelitian ini akan memperdalam masalah kinerja dan kepuasan pegawai yang bersentuhan langsung dengan aplikasi. IT Balanced Scorecard memiliki tujuan agar para pengguna dapat menyesuaikan perencanaan dan aktivitas pada sistem informasi sebagai kebutuhan organisasi, 
menyediakan pengukuran untuk mengevaluasi efektivitas sistem informasi, meningkatkan kinerja sistem informasi, dan pencapaian hasil yang seimbang di antara kelompok stakeholder.

\section{Metodologi Penelitian}

Penelitian ini dilakukan di PDAM Kota Salatiga, Jalan Letnan Jenderal Sukowati No. 66/70, Kalicacing, Sidomukti yang bergerak dalam bidang penyediaan air bersih untuk mencukupi kebutuhan air minum penduduk Kota Salatiga. Dalam penelitian ini diterapkan pendekatan kualitiatif untuk melihat dan memahami masalah berdasarkan pengalaman narasumber di PDAM Kota Salatiga yang berkaitan dengan kinerja SI/TI khususnya aplikasi pelayanan pelanggan. Pendekatan kualitatif ini dipilih karena jenis penelitian yang bergantung dari sifat objek yang akan diteliti dan biasanya penelitian tersebut terkait dengan orientasi filsafat seperti fenomenologi karena memberikan rincian yang kompleks dan harus digali lebih mendalam tentang fenomena yang terjadi oleh sebab itu biasanya sulit diungkap dengan menggunakan metode penelitian kuantitatif (Strauss \& Corbin, 2007).

Narasumber pada penelitian ini dipilih dan ditentukan dengan pertimbangan bahwa narasumber adalah orang yang ahli dan berkaitan langsung dengan aplikasi pelayanan pelanggan. Penelitian ini menggunakan data utama dari wawancara dengan narasumber pihak PDAM Kota Salatiga yaitu 1). Bapak Lauhan selaku Pengawas IT 2). Ibu Supini selaku Koordinator Bagian Pelayanan 3). Ibu Maryati selaku salah satu karyawan loket pembayaran dan 4). Bapak Brojo selaku wakil dari pihak developer aplikasi yaitu CV Duta Solusi Informatika wawancara dengan empat narasumber tersebut diperkuat dengan observasi lapangan. Data data pendukung yang digunakan berasal dari dokumen-dokumen terkait laporan evaluasi kinerja PDAM Kota Salatiga yang dipublikasikan. Data dikumpulkan dengan pengamatan seksama, mencakup deskripsi yang mendetail disertai hasil wawancara mendalam, serta analisis dokumen dan catatan-catatan.

Penelitian dimulai dari bulan November 2016 dengan melakukan observasi lapangan dan studi literatur untuk mengidentifikasi masalah dan dirumuskan sehingga didapat tujuan penelitian, setelah itu melakukan wawancara dan analisis terhadap dokumen yang terkait. Tahap analisis data dalam penelitian ini yang pertama yaitu peneliti memfokuskan hasil wawancara pada hal-hal yang penting mengenai tujuan strategi pada IT BSC bersamaan dengan membuat traskrip hasil wawancara. Selanjutnya dilakukan analisis serta interpretasi hasil wawancara yaitu memilih, merangkum, dan menyajikan dalam bentuk yang mudah dipahami. Dari hasil tersebut dilakukan triangulasi data yaitu membandingkan pernyataan semua narasumber atau dengan hasil observasi dan dokumen yang ada agar dapat memverifikasi terhadap temuan yang muncul agar dapat melihat pecapaian SI/TI dengan ukuran-ukuran kinerja pada setiap perspektif IT BSC. Tahap terakhir yaitu ditarik kesimpulan sehingga mampu memberikan rekomendasi yang dibutuhkan untuk merealisasikan tujuan strategis perusahaan dan kebutuhan.

\section{Hasil dan Pembahasan}

PDAM Kota Salatiga menggunakan aplikasi pelayanan pelanggan yang dibuat oleh pihak ke ketiga yaitu CV Duta Solusi Informatika yang berlokasi di Kota Semarang yang pertama kali digunakan pada tahun 2013 dan telah mendapat update sebanyak empat kali hingga Desember 2016. PDAM Kota Salatiga menggunakan pihak ketiga untuk membuat aplikasi pelayanan pelanggan, aplikasi tersebut menggunakan framework oracle yang memiliki tiga server untuk mengamankan data perusahaan dari faktor internal atau eksternal. Aplikasi pelanggan tersebut terbagi menjadi dua yaitu aplikasi pembayaran rekening air dan aplikasi customer service, yang akan didalami pada penelitian ini adalah aplikasi pembayaran rekening air. Secara berkala CV Duta Solusi Informatika yang diwakili oleh bapak Brojo, satu minggu sekali melakukan monitoring aplikasi.

\subsection{Kontribusi Bisnis (Business Contribution)}

Dalam perspektif ini terdapat empat sasaran yang ingin diketahui oleh peneliti yaitu keselarasan visi dan misi perusahaan terhadap TI, kejelasan wewenang antar bagian di 
perusahaan, penyerapan anggaran TI, dan nilai yang berikan TI terhadap perusahaan. Dalam perspektif ini peneliti ingin melihat bagaimana komitmen perusahaan terhadap penggunaan TI di masa depan.

Pada sasaran pertama keselarasan antara visi dan misi terhadap TI diperlukan untuk mengetahui bagaimana benang merah diantara keduanya. Dalam visi dan misi mereka yaitu Profesional artinya PDAM Kota Salatiga mampu menerapkan prinsip-prinsip manajemen untuk menjamin keberlanjutan perusahaan dalam dinamika otonomi daerah dan perkembangan IPTEK didukung SDM yang handal dan berkomitmen dan misinya yaitu menjaga hubungan harmonis dan peran yang seimbang dengan stakeholder dalam peningkatan pelayanan kepada pelanggan. Maka salah satu cara PDAM Kota Salatiga meningkatkan kualitas pelayanan mereka dengan meningkatkan kualitas TI. Peningkatan TI diharapkan dapat mempermudah kerja karyawan khususnya bagian loket pembayaran dengan membuat waktu yang digunakan untuk melayani pembayaran rekening air pelanggan menjadi lebih efisien. TI tersebut diharapkan menjawab visi misi dari PDAM yang selalu mengikuti perkembangan IPTEK. Saat aplikasi tersebut diimplementasikan, perusahaan sangat berkomitmen agar aplikasi tersebut dapat berkembang dan diadopsi pada bagian lain menyesuaikan SOP masing-masing. Ibu Supini menuturkan kondisi saat PDAM belum mengadopsi TI yang seperti sekarang sebagai berikut:

"Ndisik mas, antreane akeh banget kene sing kerjo wis maksimal padalah. Nek ngga ada sing ini(aplikasi) saya ndak tau.. bisa numpuk antrean pelanggan yang mau bayar tagihan air."

Dari penuturan tersebut terlihat bahwa karyawan sangat kesulitan melayani pelanggan ketika belum mengadopsi aplikasi tersebut. Perusahaan menyadari bahwa pengimplementasian IT harus dilakukan secara maksimal untuk meningkatkan kualitas pelayanan seperti penuturan bapak Lauhan yang menyatakan bahwa perusahaan telah sadar akan pentingnya TI dalam rangka peningkatan kualitas layanan. Dua pernyataan di atas didukung oleh data penilaian kinerja sebagaimana diatur dengan Permendagri 47 Tahun 1998 PDAM Kota Salatiga telah dinilai dengan sistem Brandmarking oleh UNDP yang bekerjasama dengan PERPAMSI, dari 15 PDAM yang berada di Jawa Tengah dan DIY PDAM Kota Salatiga memperoleh Nilai Tertinggi (Sangat Baik) dari tahun 2013 hingga 2015. Diharapkan kedepannya implementasi TI ini berkembang sehingga meningkatkan kualitas pelayanan yang lebih baik di sektor yang lain.

Pada sasaran kejelasan wewenang, peneliti ingin mengetahui bahwa penggunaan teknologi bukan hanya meningkatkan kinerja bagi karyawan, tetapi untuk memperjelas batasan wewenang antar bagian di perusahaan. Dengan menggunakan aplikasi pelayanan pelanggan ini membuat pembagian wewenang masing-masing bagian semakin jelas, karyawan hanya dapat menggunakan aplikasi sesuai tanggung jawab yang seharusnya seperti penuturan bapak Lauhan saat dilakukan wawancara. Pendapat yang diutarakan tersebut diperkuat dengan penuturan ibu Supini sebagai koordinator karyawan bagian loket pembayaran yaitu:

"Kita ndak bisa seenaknya mas..semua sudah punya password masing-masing untuk masuk ke situ..pelaporan dengan atasan juga sekarang gampang, dia ngga usah minta-minta lagi, soale kan langsung masuk ke komputernya sana".

Dari penuturan tersebut didapatkan informasi bahwa setiap karyawan memiliki password berbeda dan memiliki interface aplikasi sesuai dengan pekerjaan dan jabatan. Dengan menggunakan aplikasi pembayaran rekening air, semua aliran data dapat dimonitor oleh pemangku kebijakan secara realtime, sehingga membuat pelaporan kepada mereka semakin mudah dan cepat. Aplikasi tersebut meningkatkan efektifitas dan efisiensi kinerja karyawan dan membuat semua wewenang setiap karyawan memiliki batasan masing-masing. Diharapkan khususnya kepada karyawan bagian loket pembayaran dapat memenuhi target yang ditentukan perusahaan. Dan tahapan pembayar rekening semakin mudah dan cepat. Kejelasan terhadap wewenang masing-masing karyawan diharapkan dapat membuat kinerja setiap karyawan dapat teratur karena setiap karyawan memiliki batasan masing-masing dan meminimalisir terjadi kerancuan terhadap pekerjaan karyawan.

Pada sasaran penyerapan anggaran TI PDAM Kota Salatiga diketahui membuat rencanan anggaran untuk meningkatkan kualitas dan maintenance operasional perusahaan, rencana anggaran TI diharapkan dapat dimaksimalkan karena penyerapan anggaran yang tidak 
maksimal membuat kualitas dari alat dan aplikasi yang digunakan tidak dapat mengikuti peningkatan kebutuhan akan kualitas layanan pelanggan. Perusahaan menilai bahwa dana yang dikeluarkan sudah sesuai dengan aplikasi yang diadopsi seperti penuturan bapak Lauhan. Dari informasi yang didapat dari bapak Lauhan anggaran yang dikeluarkan perusahaan untuk maintenance dan operasional TI sebesar kurang lebih Rp. 100.000.000 per tahun. Tetapi pendapat berbeda didapatkan dari ibu Supini sebagai koordinator bagian pelayanan yang menuturkan bahwa walaupun aplikasi yang ada sudah membantu tetapi masih kekurangan fiturfitur yang dianggap penting saat peneliti menanyakan tentang ketersesuaian TI dengan kebutuhan bagian loket. Dilihat dari pendapatan perusahaan yang terus mengalami peningkatan dari tahun 2013-2015 yang mencapai Rp. 3.568.156.000 anggaran yang dikeluarkan untuk operasional dan peningkatan kualitas TI di PDAM masih belum optimal. Diperkuat dengan penuturan ibu Maryati:

"Ya itu mas, sebenere bisa lah lebih canggih lagi..tapi saya ngga tahu juga ya itukan bagian keuangannya sana pokok e yang menangani."

Tetapi saat peneliti menanyakan tentang ketersesuaian anggaran IT terhadap aplikasi menurut bapak Lauhan memang aplikasi yang ada saat ini masih perlu dikembangkan terutama pada jaringan internet. Saat observasi lapangan ditemukan bahwa jaringan internet yang ada saat ini belum dapat memenuhi kebutuhan akan kecepatan, yang mengakibatkan tersendatnya pelayanan akibat jaringan yang belum memenuhi kebutuhan. Diharapkan kedepannya terdapat peningkatan dan transparansi antar bagian dalam penyerapan anggaran TI agar masalah seperti jaringan dan fitur aplikasi belum memenuhi kebutuhan dapat dihindari. Karena TI terus berkembang selaras dengan perkembangan zaman, maka pembaharuan perangkat dan pengoptimalisasian jaringan internet sangat diperlukan untuk mendukung aplikasi atau sistem yang baru.

Pada sasaran nilai yang di berikan TI terhadap perusahaan, kehadiran aplikasi pelayanan pelanggan diharapkan berdampak baik bagi kemajuan perusahaan. Aplikasi pembayaran rekening air yang berbasis desktop ini sangat dirasakan manfaatnya oleh karyawan bagian loket pembayaran. Penggunaan aplikasi pelayanan pelanggan ini tentunya dapat memberikan suatu nilai tambah untuk perusahaan seperti kualitas layanan, pengurangan tunggakan tagihan pelanggan, dan efisiensi karyawan dalam bekerja. Aplikasi yang ada saat ini diharapkan dapat memenuhi kebutuhan terhadap TI untuk meningkatkan kualitas layanan agar mencapai target dari perusahaan seperti ibu Supini yang menuturkan bahwa target yang harus dicapai oleh karyawan khususnya bagian loket pembayaran adalah terjadi penurunan tunggakan pembayaran. Pendapat yang diberikan oleh ibu Supini merupakan sebuah informasi bahwa perusahaan mengharapkan aplikasi tersebut untuk dapat memberikan keuntungan bagi perusahaan. Dengan pencapaian tersebut perusahaan diharapkan mendukung perkembangan TI, karena dengan TI pekerjaan yang biasanya dikerjakan oleh beberapa orang dapat dikerjakan oleh satu orang seperti penuturan bapak Lauhan:

"Sak durunge pakai program ini satu loket dua orang sekarang kan satu orang..dua orang itu lama (dahulu). Satu orang yang mencari satu orang yang menarik seperti itu”.

Yang dimaksud adalah ketika belum menggunakan aplikasi pelayanan pelanggan, dua orang dibutuhkan untuk satu loket, dan waktu yang dibutuhkan untuk melayani pelanggan masih lama, bapak Lauhan juga menuturkan bahwa perusahaan sangat merasakan peningkatan dari berbagai perspektif seperti pengefisiensian waktu dan tenaga kerja. Dua pendapat di atas didukung oleh data pencapaian kinerja yang diperoleh PDAM Kota Salatiga meningkat dari tahun 2012 hingga 2015 yang mendapat predikat SEHAT dari BPPSPAM dan hasil audit BPKP memperoleh Predikat WTP (Wajar Tanpa Pengecualian). Dengan melihat peningkatan pada data di atas perusahaan telah menyadari jika mereka hanya mengandalkan cara yang lama, maka akan terjadi penurunan kualitas layanan yang ada. Diharapkan pada tahun-tahun berikutnya perusahaan akan mendapat nilai yang tinggi untuk pencapaian kinerja dan terus meningkatkan mutu dari aplikasi yang ada saat ini. Karena dari beberapa pernyataan dan gambar di atas dapat dilihat capaian perusahaan sangat bagus dan terus terjadi peningkatan dari tahun 2013. 


\subsection{Orientasi Pengguna (User Orientation)}

Dalam perspektif ini terdapat tiga sasaran yang ingin diketahui oleh peneliti yaitiu kualitas aplikasi dan jaringan yang tersedia, kepuasan pengguna terhadap aplikasi, dan evaluasi terhadap aplikasi. Dalam perspektif ini peneliti ingin melihat bagaimana pandangan dari sisi pengguna apakah aplikasi dan sarana pendukung yang ada telah sesuai dengan yang mereka butuhkan dan inginkan.

Pada sasaran kualitas aplikasi dan jaringan untuk memenuhi kebutuhan akan kecepatan internet, diketahui jaringan yang dipakai memiliki kecepatan satu Mbps untuk server dan 10 Mbps untuk umum. Aplikasi pelayanan pelanggan dilakukan monitoring secara berkala oleh pihak developer untuk mengetahui dan memperbaiki kendala-kendala yang terjadi. Aplikasi yang digunakan diharapkan dapat memenuhi kualitas layanan yang semakin meningkat secara tepat. Dalam hal kecepatan pelayanan pelanggan, menurut ibu Maryati sebagai salah satu karyawan bagian loket pembayaran sudah lebih baik jika dibandingkan sebelum menggunakan aplikasi karena dalam waktu lima menit mereka dapat melayani tiga hingga lima pelanggan dalam situasi normal, yang dimaksud normal disini pelanggan sudah maju dengan menyediakan rekening air, nomor antrian, dan uang pembayaran. Saat melakukan wawancara terhadap rensponsifitas aplikasi, menurut ibu Supini aplikasi yang ada saat ini telah membantu kinerja karyawan khususnya pada bagian loket pembayaran, akan tetapi masih perlu pembaharuan sebagai berikut:

"Ya masih gimana ya..masih kurang canggih sedikitlah masih lemot, masih kurang..pokoknya perlu pembaharuan lagi lah."

Dari penuturan tersebut didapatkan informasi bahwa kualitas jaringan internet yang tersedia dan fitur-fitur yang terdapat pada aplikasi masih belum memenuhi kebutuhan di PDAM. Saat diadakan wawancara kepada ibu Supini di hari berikutnya, beliau menuturkan bahwa beliau mengalami kebingungan saat menggunakan aplikasi yang baru ter-update tersebut. Pernyataan diatas diperkuat dengan pernyatan dari bapak Lauhan:

“..untuk problem aplikasi tu kebanyakan yang kemarin itu pas saat developing aplikasi ini kurangnya fitur aja, jadi kalo problemnya kita belum pernah jadi paling kekurang fitur-fitur di apa..di apa.."

Dari penuturan tersebut dapat diperoleh informasi bahwa aplikasi tersebut masih kekurangan fitur yang berdampak terhadap kinerja dari karyawan bagian loket pembayaran. Walaupun secara kebutuhan dasar pelayanan sudah terpenuhi, namun kebutuhan akan kecepatan jaringan dan kecanggihan aplikasi harus selaras dengan peningkatan kebutuhan yang ada. Dari hasil wawancara yang dilakukan dengan karyawan bagian loket pembayaran ditemukan bahwa komunikasi dengan pihak TI belum berjalan dengan baik seperti penuturan ibu Supini ketika keluhan beliau tentang aplikasi tersebut tidak kunjung ditangani oleh pihak TI ataupun developer. Karena saat aplikasi tersebut tidak dapat memenuhi kebutuhan yang terus meningkat dikhawatirkan terjadi penurunan kinerja. Peningkatkan komunikasi antara pihak ketiga dan PDAM Kota Salatiga sangat diperlukan agar masalah-masalah seperti kekurangan fitur dan kurang cepatnya jaringan dapat diatasi dengan baik. Hal ini akan berdampak kepada kepuasan pengguna terhadap aplikasi, ditambah dengan tidak adanya alur pelaporan khusus saat terjadi error pada sistem. Diharapkan pihak PDAM dan developer dapat berkomunikasi dengan lebih baik untuk meningkatkan kualitas jaringan internet dan fitur aplikasi agar lebih responsif. Aplikasi yang user friendly diperlukan untuk mempermudah karyawan memahami perubahan atau penambahan fitur pada aplikasi tersebut.

Sasaran kepuasan pengguna terhadap aplikasi ditekankan kepada pandangan pengguna terhadap aplikasi yang digunakan saat ini. Aplikasi pelayanan pelanggan ini digunakan sejak tahun 2013, karena terjadi peningkatan jumlah pelanggan PDAM Kota Salatiga, dan dirasa cara lama yang disampaikan oleh ibu Maryati sudah tidak efektif:

"Seperti itu karena masih ada rekening seprerti ini (sambil menunjukan struk rekening yang lama) masih dicetak kita kan mencari no nosa nya dulu perorangan dulu ini bukai dulu daerah mana seperti itu. Sekarang kan kita ndak ngethoki (cap), masih nyueki.." 
Dari penuturan tersebut menyebutkan jika sebelum menggunakan aplikasi tersebut, satu loket berisi dua orang tetapi masih memakan waktu yang lama untuk melayani pembayaran rekening air karena satu karyawan bertugas untuk mencari nomor nasabah, memberi cap lunas, memotong struk lama dan karyawan lain bertugas menerima uang. Para karyawan bagian loket pembayaran sangat terbantu dengan adanya aplikasi ini, tetapi disatu sisi terdapat kendala yang disampaikan ibu Supini sebagai berikut:

“..ya sangat membantu sekali cuma ada pembaharuan lah wong namanya.. wong yang itu kan juga manusia ya, kadang ada lemotnya, kadang-kadang listrik mati pengaruh seperti itu, nanti kan otomatis pengaruh."

Dari penuturan tersebut didapatkan informasi bahwa peningkatan kualitas aplikasi dan peningkatan manajemen risiko yang dapat mempengaruhi kinerja karyawan loket pembayaran. Peningkatan pelanggan harus selaras dengan teknologi yang ada dituntut semakin canggih. Diharapkan kedepan aplikasi dapat ditingkatkan, sehingga terjadi peningkatan efisiensi kualitas layanan pada bagian loket pembayaran. Dari hasil observasi dan wawancara PDAM memiliki tiga server untuk menampung data, akan tetapi aplikasi yang digunakan saat ini masih berbasis desktop yang dinilai bapak Lauhan terlalu banyak kendala yang mungkin terjadi seperti harus install ulang aplikasi saat dilakukan update. Diharapkan pembaharuan aplikasi berbasis web dan jaringan yang sering menjadi kendala dapat diperbaiki untuk meningkatkan efektifitas dan efisiensi karyawan.

Pada sasaran evaluasi terhadap aplikasi, yang ingin diketahui adalah bagaimana evaluasi yang dilakukan pihak PDAM untuk mengetahui komunikasi berbagai pihak terkait. Evaluasi dimaksudkan untuk mengetahui apa yang dibutuhkan karyawan terhadap aplikasi agar tidak terjadi kesalahan dalam pengartian antara karyawan, pihak IT dan developer aplikasi. Dari hasil wawancara dengan bapak Lauhan beliau menuturkan:

"Kita tidak menjadwalkan harus satu bulan sekali, tergantung usernya. Tergantung user nah.. disitu user ada mendapat kendala mereka langsung..di situ langsung kita lakukan evaluasi, saat terjadi komplain user.."

Dari penuturan tersebut didapatkan informasi bahwa evaluasi hanya dilakukan jika terjadi masalah pada aplikasi yang dikeluhkan oleh karyawan bagian loket pembayaran. Pihak IT PDAM Kota Salatiga menganggap bahwa evaluasi khusus tidak diperlukan jika tidak terjadi masalah terhadap aplikasi. Tetapi berbeda dari penuturan di atas, menurut ibu Supini selaku koordinator bagian pelayanan beliau menyampaikan bahwa jika terjadi masalah mereka langsung melaporkan kepada pihak IT PDAM atau developer aplikasi saat mereka melakukan monitoring secara berkala ke PDAM, tetapi saat peneliti menanyakan apakah para karyawan bagian loket diikutsertakan dalam rapat atau pertemuan saat membahas kendala yang disampaikan, beliau menuturkan bahwa kurang mengetahui hal itu. Dari dua penuturan di atas didapatkan informasi bahwa pihak IT PDAM belum mengadakan semacam evaluasi untuk membahas lebih secara mendalam kendala atau fitur yang ingin ditambahkan antara developer, pihak IT PDAM dan karyawan yang menggunakan aplikasi tersebut, padahal dengan melakukan evaluasi yang dihadiri berbagai pihak sangat penting untuk mengetahui lebih mendalam apa yang dibutuhkan dan diinginkan dari pengguna aplikasi agar tidak terjadi kesalahan dalam pengartian yang dapat mengakibatkan fitur yang dibuat untuk menangani masalah tidak dapat digunakan yang berdampak terhadap penurunan kinerja. Merujuk kepada perspektif kesempurnaan operasional pada pelaporan kegagalan sistem pada PDAM Kota Salatiga belum memiliki alur pelaporan yang baik. Diharapkan kedepan terdapat evaluasi secara yang dihadiri oleh semua pihak yang terkait dengan aplikasi tersebut. Karena dapat menyelaraskan pemikiran dan keinginan mereka maka kesalahan dalam pengartian kebutuhan ini dapat diminimalisir.

\subsection{Kesempurnaan Operasional (Operational Excellence)}

Dalam perspektif ini terdapat dua sasaran yang ingin diketahui oleh peneliti adalah pelaporan kegagalan sistem dan komunikasi dengan pihak terkait. Dalam perspektif ini peneliti ingin melihat bagaimana sisi operasional aplikasi hal ini penting bagi kelancaran penggunaan aplikasi dan komunikasi terhadap berbagai pihak. 
Pada sasaran pelaporan kegagalan sistem ingin dilihat bagaimana alur pelaporan jika terjadi masalah terhadap aplikasi. Alur pelaporan biasanya terdapat pada standar operasional prosedur (SOP) pada setiap perusahaan. Hal ini dibutuhkan bukan hanya mengedukasi karyawan terhadap penggunaan, alur aplikasi yang digunakan dan tanggung jawab mereka masing-masing tetapi juga alur pelaporan jika terjadi masalah dengan aplikasi. Pada PDAM Kota Salatiga SOP yang digunakan masih menggunakan SOP yang lama saat aplikasi ini belum diimplementasikan seperti penuturan bapak Lauhan. Dari penturan beliau didapatkan informasi bahwa SOP yang digunakan saat ini masih menggunakan SOP tahun 2013 dan belum memasukan SOP terhadap aplikasi yang digunakan. SOP sangat penting untuk mengedukasi para karyawan tentang penggunaan aplikasi, alur aplikasi dan alur pelaporan masalah. Walaupun aplikasi yang ada dirasa sangat membantu karyawan bagian loket pembayaran, tetapi menurut ibu Supini saat terjadi masalah seperti error pada aplikasi, beliau menuturkan:

“..tapi biasanya mas Ohan (Pak Lauhan) atau mas Ferdian tapi aku sendiri nggak tahu siapa yang dituju sebetulnya itu siapa, tapi yang paling banyak ini deng (dengan menunjuk pak Lauhan)..yang tahu itu, ferdian aja ngga tahu deng, betul itu.."

Dari penuturan tersebut didapatkan informasi bahwa alur pelaporan saat error belum jelas sehingga terlihat dari penuturan tersebut terjadi kebingungan pada karyawan. Oleh karena itu ibu Supini hanya melapor kepada satu orang. SOP yang seharusnya memuat prosedur penggunaan aplikasi dan pelaporan masalah masih belum diperbaharui. Hal ini sering menjadi kebingungan saat karyawan menemukan masalah terkait aplikasi. Seharusnya SOP tersebut dibuat untuk pengguna aplikasi sebagai acuan mereka saat menggunakan aplikasi dan alur pelaporan dibuat dengan jelas agar para karyawan PDAM Kota Salatiga seakan-akan hanya melaporkan masalah terkait aplikasi kepada satu orang. Padahal menurut bapak Lauhan pihak ketiga, selalu datang untuk memonitoring secara berkala aplikasi yang dibuatnya satu minggu sekali, akan tetapi menurut penuturan ibu Supini yang merujuk pada sasaran komunikasi dengan pihak terkait terlihat tanggapan pihak developer dalam menerima laporan belum maksimal. Diharapkan ada pembaharuan SOP sesuai dengan perubahan aplikasi yang digunakan, dengan adanya SOP ini karyawan bagian loket pembayaran juga mengetahui alur pelaporan masalah terhadap aplikasi dengan jelas. Penambahan bagian khusus yang menangani kendala yang disampaikan oleh karyawan dirasa perlu agar karyawan tidak kebingungan saat mereka menemukan kendala atau saat mereka ingin memberi masukan terkait kemajuan aplikasi.

Pada sasaran komunikasi dengan pihak terkait dilihat komunikasi antara pihak PDAM dengan pihak developer sangat penting untuk diketahui untuk pengembangan aplikasi. Pada PDAM Kota Salatiga komunikasi yang terjadi antara developer aplikasi dan karyawan PDAM dirasa masih kurang baik, karena ditemukan berbagai kendala yang diutarakan oleh bagian loket pembayaran khususnya belum terselesaikan padahal pihak developer menjadwalkan monitoring aplikasi satu minggu sekali. Saat peneliti melakukan wawancara dengan ibu Supini beliau menuturkan sebagai berikut:

"Aku njaluk itu lho, sampe tak otak atik dewe..sampe ketemu lha pak Brojo sama mas Ohan (pak Lauhan) bikin, pak Brojo: "oh iya siap" sampe semene nyatane yo..ora lek iki..."

Yang dimaksud oleh ibu Supini adalah permintaan yang beliau sampaikan, hingga beliau mengotak-atik aplikasi sendiri dan padahal bapak Brojo mengatakan bersedia membuat fiturfitur yang dibutuhkan sampai saat ini belum ada realisasinya. Dari penuturan tersebut terlihat bahwa saat aplikasi tersebut diupdate beliau masih belum paham akan fitur-fitur baru pada aplikasi hingga mencarinya sendiri. Wawancara tersebut dilakukan bersama bapak Lauhan selaku IT PDAM dan beliau hanya menuturkan belum bisa membuat, akan tetapi tidak diungkapkan alasan terkait hal tersebut. Merujuk dari pada perspektif orientasi masa depan training yang dituturkan oleh bapak Lauhan terlihat belum membuat para karyawan mengerti akan penggunaan fitur baru pada aplikasi. Diharapkan agar tidak terjadi salah pengartian terhadap permintaan yang disampaikan yang akan berdampak terhadap terhambatnya produktivitas karyawan dalam menggunakan aplikasi tersebut. Komunikasi berbagai pihak terkait aplikasi juga seharusnya dapat dilakukan dengan lebih baik, training terhadap karyawan diharapkan dapat dilakukan lebih intensif agar karyawan bagian loket pembayaran tidak 
mengalami kebingungan dengan perubahan atau penambahan fitur aplikasi. Aplikasi yang user friendly juga diperlukan agar karyawan bagian loket pembayaran dapat memahami aplikasi dengan lebih baik jika merujuk dari perspektif orientasi pengguna.

\subsection{Orientasi Masa Depan (Future Orientation)}

Dalam perspektif ini terdapat tiga sasaran yang ingin diketahui oleh peneliti adalah peningkatan kualitas SDM, kepuasan karyawan terhadap perusahaan dan peningkatan kualitas aplikasi. Dalam perspektif ini peneliti ingin melihat harapan dari sisi karyawan terhadap kemajuan aplikasi dan kepuasan karyawan terhadap perusahaan.

Pada sasaran peningkatan kualitas aplikasi, karyawan adalah suatu bagian yang penting bagi sebuah organisasi atau perusahaan. Kemampuan karyawan sangat menentukan sukses atau tidaknya sebuah perusahaan dalam persaingan. Pada PDAM Kota Salatiga sendiri memiliki berjumlah 137 orang pada tahun 2015. Karyawan bagian IT sendiri sebanyak tiga orang sebagai admin aplikasi dan satu orang sebagai pengawas IT. Menurut bapak Lauhan untuk karyawan di bagian IT sendiri dirasa cukup. Tetapi merujuk dari salah satu sasaran perspektif kepuasan pengguna, ibu Supini menuturkan bahwa salah satu IT mereka belum tanggap dalam hal penyelesaian masalah terkait aplikasi pembayaran rekening. Diperlukan bagian khusus untuk pelaporan dan perbaikan, jika terjadi error terhadap aplikasi sebagai penanganan pertama walaupun bapak Lauhan menuturkan bahwa pihak developer aplikasi secara berkala datang ke PDAM untuk melakukan monitoring aplikasi tersebut. Karyawan yang menggunakan aplikasi tersebut diharuskan melakukan training sebelum menggunakan aplikasi seperti penuturan ibu Supini. Akan tetapi menurut bapak Lauhan training tersebut tidak diadakan secara khusus, karena mengikuti dari kemampuan masing-masing karyawan untuk mengerti penggunaan aplikasi tersebut. Pelatihan terhadap pembaharuan aplikasi ini bertujuan untuk mengedukasi karyawan khususnya bagian loket pembayaran tentang fitur-fitur baru yang dibuat untuk meningkatkan kinerja mereka. Pelatihan terkait aplikasi yang ada belum diadakan secara khusus dikarenakan fitur-fitur yang ditambahkan selama ini sangat dianggap mudah dipahami dan digunakan. Diharapkan kedepannya PDAM memiliki karyawan IT yang dikhususkan untuk menangani masalah yang terjadi pada jaringan dan aplikasi, bukan hanya mengandalkan dari pihak developer, setidaknya sebagai penanganan pertama. Karena pada saat digunakan terjadi kendala maka tidak harus menunggu dari pihak developer untuk datang, karena sangat memakan waktu.

Sasaran kepuasan karyawan terhadap perusahaan ingin dilihat apakah perusahaan memberikan kompensasi atau reward kepada karyawan yang dapat memenuhi target yang ditentukan. Menurut penuturan ibu Supini PDAM Kota Salatiga belum memberikan karyawan suatu reward atau kompensasi jika para karyawan dapat memenuhi target yang telah ditetapkan, khususnya untuk bagian loket pembayaran seperti penuturan beliau:

"Wah selama ini belum ada."

ketika peneliti menanyakan tentang bonus atau kompensasi yang diberikan perusahaan, hal ini dikarenakan target yang diberikan oleh perusahaan adalah target secara umum seperti di bagian loket pembayaran, perusahaan memberi target untuk meminimalkan tunggakan pembayaran, tidak ada target secara khusus yang seharusnya dapat memicu karyawan untuk bekerja dengan lebih baik. Ketika peneliti menanyakan tentang kepuasan bekerja kepada ibu Maryati beliau menuturkan sudah bagus tapi perlu ada peningkatan. Ketika karyawan mendapatkan suatu reward atau kompensasi saat mereka mencapai target yang telah ditentukan, akan berdampak baik bagi perusahaan karena kepuasan karyawan terhadap perusahaan akan meningkat dan loyalitas karyawan akan bertambah. Pemberian reward atau insentif dapat menjadi bentuk apresiasi yang diberikan perusahaan dan membantu meningkatkan kinerja karyawan PDAM Kota Salatiga yang akan berdampak kepuasan karyawan terhadap perusahaan.

Dalam sasaran peningkatan kualitas aplikasi ingin diketahui apa yang karyawan inginkan untuk aplikasi pelayanan pembayaran rekening di masa depan. Karena teknologi akan selalu berkembang memenuhi kebutuhan permintaan layanan yang lebih baik. Aplikasi pelayanan pelanggan sangat membantu dalam menyelesaikan tugas serta meningkatkan 
pelayanan, dalam hal ini aplikasi pelayanan pelanggan diharapkan terus dikembangkan untuk memenuhi kebutuhan yang terus meningkat seperti penuturan bapak Lauhan:

"Kalo kedepannya saya malah menginginkan aplikasi ini dijadikan web base, jadi bukan desktop lagi karena apa ya..terlalu ribet kalo kita harus install di setiap PC padahal PC kadang ada rusaknya, ada penambahan baru.."

Dari penuturan tersebut didapatkan informasi bahwa aplikasi berbasis desktop saat ini masih memiliki banyak celah yang dapat menurunkan kinerja karyawan seperti perangkat error dan perangkat harus install ulang jika mengalami penambahan fitur. Modernisasi aplikasi sangat dibutuhkan, karena dengan begitu kendala yang mungkin terjadi bisa diminimalisir. Bahkan dari wawancara, ibu Supini membandingkan dengan perusahaan pemerintah lain:

"Tidak ada kemacetan, jadi lebih sedikit yang laporan. Umpamanya seperti PLN saya tahu tujuannya itu dia pakai pulsa mengurangi yang laporan ke sana..struk dibikin lebih simple jadi semua orang..maksudnya orang awam pun bisa tahu, Cuma itu doang"

Dapat dilihat bahwa yang diharapkan dari karyawan bagian pelayanan pelanggan adalah suatu aplikasi yang dapat digunakan dengan mudah dan menghasilkan output yang mudah dimengerti bahkan oleh pelanggan. Menurut ibu Supini yang diharapkan untuk aplikasi tersebut kedepannya adalah aplikasi tersebut dapat menghasilkan output yang lebih mudah dipahami bahkan untuk orang awam sekalipun. Karena banyak dari karyawan baru yang masih bingung jika mengartikan output yang dihasilkan oleh aplikasi tersebut. Ketika melihat dari kedua penuturan di atas bahwa aplikasi berbasis web dan aplikasi yang memiliki output yang dapat dipahami oleh semua orang seharusnya menjadi yang diharapkan oleh orang yang terkait langsung dengan aplikasi tersebut.

\subsection{Hasil Analisis IT BSC}

Selanjutnya dilakukan analisis terhadap hasil dan harapan yang dipaparkan pada setiap perspektif di atas untuk memetakan temuan-temuan untuk selanjutnya dapat memberikan rekomendasi pada PDAM Kota Salatiga. Hasil analisis ini dapat dilihat di Tabel 1.

Tabel. 1 Hasil Analisis Pada Perspektif IT BSC

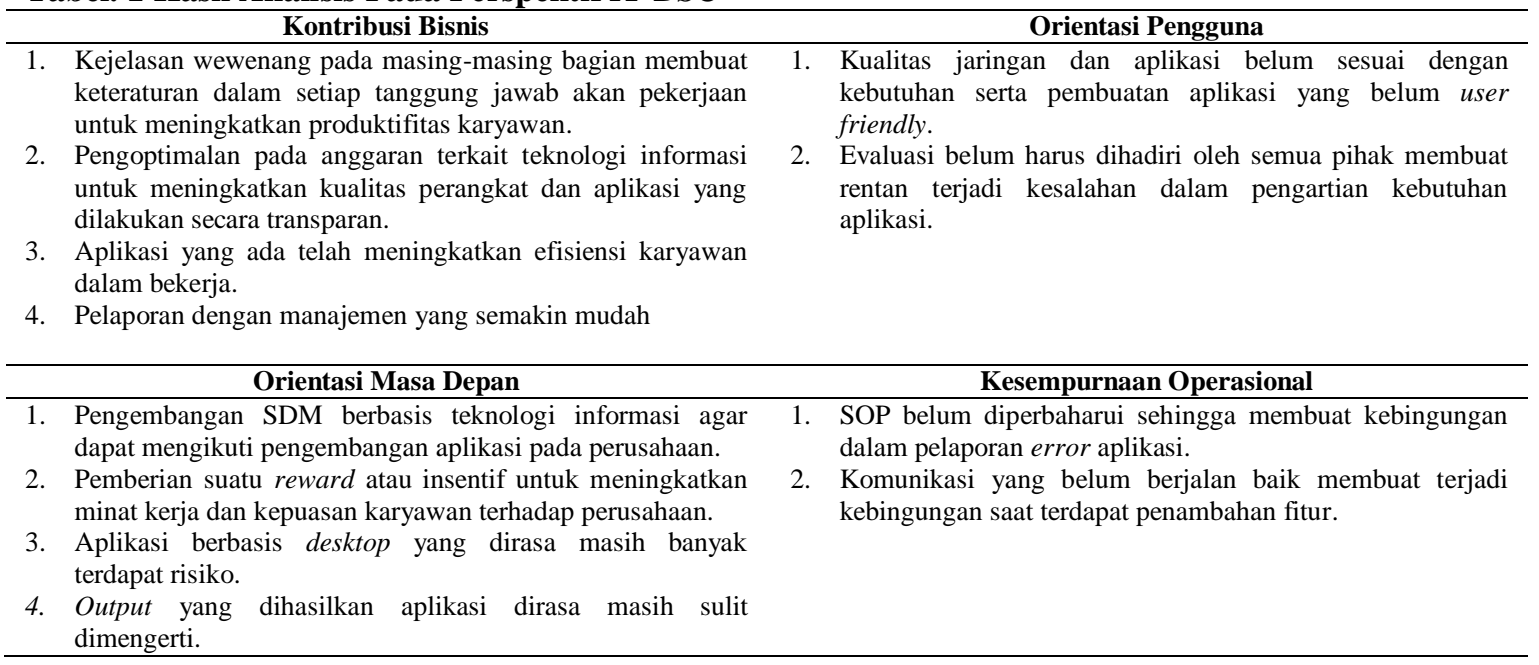

Terlihat masalah komunikasi antara pihak IT, developer, karyawan bagian loket pembayaran masih menjadi kendala utama dalam proses pengembangan aplikasi, ketika terdapat komunikasi yang baik antar berbagai pihak maka proses pengembangan aplikasi kedepan akan meminimalkan kesalahan dalam pengartian kebutuhan dan meningkatkan kelancaran operasional. 


\section{Kesimpulan}

Berdasarkan penelitian terhadap kinerja SI/TI pada PDAM Kota Salatiga, maka dapat diambil kesimpulan bahwa kinerja SI/TI khususnya aplikasi pelayanan pelanggan telah memenuhi kebutuhan dasar terhadap perkembangan teknologi dan peningkatan pelanggan serta dapat meningkatkan efisiensi dan efektifitas karyawan yang berdampak terhadap peningkatan kinerja karyawan. Hal ini terlihat pada perspektif kontribusi bisnis, aplikasi pembayaran rekening air memiliki peranan penting dalam mengurangi antrian pelanggan dan mengoptimalkan tenaga kerja perusahaan. Dampak kehadiran aplikasi tersebut juga terlihat pada kemudahan aksesbilitas informasi yang membuat pemangku kebijakan dapat memonitoring pegawai secara langsung, sehingga pelaporan yang dahulu membuat karyawan merasa kesulitan dengan aplikasi tersebut membuat pelaporan karyawan bagian loket pembayaran lebih cepat dan mudah.

Di sisi lain dalam penelitian ini terdapat beberapa kendala yang harus segera diperbaiki adalah komunikasi antara PDAM dan developer aplikasi yang belum dilakukan secara maksimal sehingga menghambat dalam pengembangan aplikasi pelayanan pelanggan, serta kendala lain yang muncul yaitu: 1). Jaringan yang ada saat ini belum dapat memenuhi kebutuhan aplikasi yang terus meningkat. 2). Aplikasi yang ada saat ini belum user friendly. 3). Evaluasi yang dilakukan belum optimal. 4). SOP belum diperbaharui dari tahun 2013. 5). Training yang dilakukan dirasa belum dapat membuat pengguna memahami aplikasi yang baru. 7). Penyederhanaan output yang dihasilkan aplikasi. 8). Aplikasi masih berbasis desktop yang memiliki banyak risiko.

Mengacu pada pemahaman tersebut, maka diharapkan adanya kebijakan perusahaan dan perhatian lebih untuk meningkatkan aplikasi di masa depan yang akan berdampak kepada kepuasan pengguna dan peningkatan kualitas layanan PDAM Kota Salatiga. Perusahaan dapat menjadi jembatan yang dapat menghubungkan semua pihak yang terlibat untuk dapat menciptakan komunikasi yang lebih baik.

\section{Referensi}

Afrianto, I. (2010). Usulan Peta Strategi Teknologi Informasi Menggunakan Pendekatan Balanced Scorecard (Studi Kasus Kantor Direksi PT. X). Majalah Ilmiah UNIKOM, 9(1).

Arofah, N., Sholiq, \& Nisafani, A.S. (2012). Penyusunan IT Balanced Scorecard Untuk Pengukuran Kinerja Divisi IT di PT. Pertamina UPMS V Surabaya. Jurnal Teknik POMITS, 1(2), 1-9.

Hidayanto, A.N., Ahmadin, Y., \& Jiwanggi, M.A. (2012). Pengukuran Tingkat Dukungan Teknologi Informasi Pada Direktorat Transformasi Teknologi Komunikasi Dan Informasi, Direktorat Jenderal Pajak Dengan Menggunakan IT Balanced Scorecard. Jurnal Sistem Informasi, 6(2), 117-125.

Kaplan, R.S., \& Norton, D.P. (2006). Alignment: Using the balanced scorecard to create corporate synergies. Harvard Business Press.

Kosasi, S. (2015). Pengukuran Kinerja Web Brinet System Dengan Metode IT Balanced Scorecard. Jurnal Buana Informatika, 6(1), 1-10.

Legoh, G.S., \& Tambotoh, J. (2015). Analisa Kinerja Sistem Informasi /Teknologi Informasi Pada BPPT dan PM Kota Salatiga Menggunakan Kerangka IT Balanced Scorecard. Seminar Nasional Teknologi Informasi dan Komunikasi Terapan (SEMANTIK).

Maula, K., \& Ghozali, K. (2012). Evaluasi kinerja IT pada PT XYZ menggunakan IT balanced scorecard. Jurnal Teknik POMITS, 1(1), 1-6.

Solechan, A. (2015). Tata Kelola Kinerja Teknologi Informasi Menggunakan IT Balanced Scorecard (Studi Pada Stmik Provisi Semarang). Jurnal Teknologi Informasi dan Komunikasi, 6(2), 61-66.

Strauss, A., \& Corbin, J. (2007). Dasar-dasar Penelitian Kualitatif, Tata Langkah dan TeknikTeknik Teorisasi Data. Yogyakarta. Penerbit: Pustaka Pelajar. 
192 Jurnal Buana Informatika, Volume 8, Nomor 4, Oktober 2017: 181-192

Wijaya, R. (2015). Analisis Model IT Menggunakan Balanced Scorecard Untuk Pengembangan Sistem Teknologi Informasi. Jurnal Sistem Informasi, 2(1), 3-7. 